\title{
DEBATT
}

\section{Svar till Gunnar Alsmark angående chefsintervjuer}

\section{DAVID W ÄSTERFORS}

Med anledning av Gunnar Alsmarks kritik av mina reflektioner kring kvalitativa chefsintervjuer i förra numret av denna tidskrift vill jag förtydliga några saker och om möjligt reda ut några missförstånd.

Gunnar Alsmark fastnar för mitt påståendeomattsociologer utmärksav ettsjälvkritiskt förhållande till intervjuer som metod. Sedan skriver han en lång utläggning för att beklaga skiljelinjerna mellan sociologer och etnologer och för att understryka etnologers djupa kunskap om kvalitativa intervjuer. Detta har jag aldrig ifrågasatt. Alsmark diskuterar mitt påstående taget ur sitt sammanhang. Som tydligt framgår i min artikel skrev jag i dess inledning inte om sociologers syn på intervjuer jämfört med andra forskares syn på intervjuer, utan jämfört med grupper utanför universitetsvärlden, till exempel reklambyråer, terapeuter och journalister. Min enkla poäng var att även dessa använder intervjuer, men sällan utifrån samma metodologiska betraktande som inom universitetsvärlden. Jag kunde lika gärna ha skrivit om etnologers särskildhet i detta sammanhang, eller om humanister och samhällsvetare i allmänhet.
Vidare är Gunnar Alsmark avvisande till mitt sätt att beskriva intervjuarens position med hjälp av dikotomin aktiv-passiv. Här vill jag delvis ge Alsmark rätt. Begreppsparet är problematiskt och extremt förenklande, liksom min avslutande figur där jag kombinerar detta begreppspar med den intervjuades tänkbara chefsposition. Denna figur skulle jag i efterhand vilja stryka. Den fördunklar mer än den förklarar. Samtidigt är jag i min text noga med att påpeka att begreppsparet aktiv-passiv inte ska ses som heltäckande vad gäller intervjuarens förhållningssätt. Det fokuserar enbart en aspekt av intervjuarens handlingar: att medvetet aktivera eller undvika att aktivera alternativa narrativa resurser hos den intervjuade under själva samtalet. Ett sådant synsätt har jag inte hittat på själv. Som framgår i texten har jag tagit det från James A. Holsteins och Jaber F. Gubriums idé om "active interviewing".

Detärisjälva verketdennamycket begränsadeaspekt av en intervju min artikel handlar om; intervjuarens möjlighet att ifrågasätta, be om förklaringar, byta ämne, avbryta och haka på antydningar om alternativa berättelser - samt att denna möjlighet kan bli extra 
viktig att beakta om den som intervjuas är en van och skicklig talare, såsom många chefer.

Jag skriver alltså inte om hela intervjusituationen. I efterhand inser jag att detta borde ha specificerats i textens inledning. Då hade det även blivit begripligt varför jag inte tar upp alla de begrepp och teman Gunnar Alsmark säger sig sakna, till exempel etik, förförståelse och tolkningsarbete. Jag har aldrig hävdat att dessa skulle vara betydelselösa.

Gunnar Alsmark anser också att mina reflektioner är "kokbokspräglade» trots att jag ordagrant skriver att de inte ska uppfattas som ett universellt recept. Att jag inte refererar till de böcker Gunnar Alsmark vill att jag ska referera till kan jag inte heller se som särskilt kokbokspräglat och det är inte detsamma som att »slå in öppna dörrar». Att enbart citera från litteratur är väl snarare att slå in öppna dörrar. Litteraturen kan ju med större fördel läsas direkt.

Det är möjligt att min artikel är alltför trivial och självklar utifrån Gunnar Alsmarks synvinkel. Jag är inte säker på att alla läsare tycker likadant. Idealet med en intervjuare som rutinmässigt intar entydigt sympatiska och följsamma positioner är kanske vanligare än man tänker sig, åtminstone bland samhällsvetenskapliga nybörjare. Min artikel var varken mer eller mindre än ett försök att utifrån några texter och egna erfarenheter fundera över detta ideal. Tidskriften förvandlade den till en »debattartikel» och Gunnar Alsmark såg den som polemik mot etnologer. Det kan jag bara förvånas över och beklaga.

DavidWästerfors

\section{Debatt eller bedömning?}

\section{Replik till Alsmark \\ HÅKAN JÖNSON}

Jag ställer mig undrande inför det sätt på vilketSocialvetenskaplig tidskriftoch docent Gunnar Alsmark behandlat David Wästerfors artikel om att intervjua chefer. Alsmark har flera poänger i sin kritik av artikeln. Det är emellertid inte dessa jag ska diskutera här. I stället ska jag föra ett konspirationsteoretiskt resonemang, som går ut på att redaktionen för Socialvetenskaplig tidskrift utnyttjat Wästerfors artikel för att få till en debatt (om vad som helst) i tidskriften.
Wästerfors artikel står under rubriken Debatt, men var det verkligen en debattartikel han skickade in till tidskriften? Artikelns uppbyggnad och argumentation leder inte tanken åt det hållet. Wästerfors ställer visserligen upp sin ansats mot den påstådda föreställningen om att intervjuare ska minimera sin onaturliga påverkan, men det är då frågan om ett traditionellt sätt att formulera ett vetenskapligt problem. Själv tycker jag (utan att bedöma artikelns kvaliteter) att 
ett mer naturligt sammanhang hade varit avdelningen för Metodologiska reflektioner. Som jag förtstått saken var det till den avdelningen artikeln ursprungligen skickades in.

Så till Alsmarks replik till Wästerfors. Det är tre saker som gör mig fundersam när jag läser denna. För det första uppträder den i samma nummer som Wästerfors artikel. Det naturliga hade väl varit om den kommit i det påföljande numret? För det andra är Alsmark medlem av tidskriftens redaktion, ett faktum som är av fundamental betydelse, men som utelämnas när han presenteras $\mathrm{i}$ anslutning till sin artikel. För det tredje är Alsmarks artikel atypisk som replik, eftersom den mer bedömer artikelnän debatterar metoden. Wästerfors artikel saknar enligt Alsmark originalitet, eftersom det är självklart attallaintervjuare måste reflekteraöver sitt agerande, vare sig de intervjuar chefer eller andra. Artikeln saknar diskursivitet, eftersom den inte anknyter till svensk forskning inom etnologi bl.a. Det saknas viktig information och reflexioner om de chefer Wästerfors intervjuat. Artikeln bedöms vara naiv och av för låg kvalitet för SVT:s läsekrets. Jag tror inte att en så lång och spretande"replik" hade bedömts duglig för publicering om den s.a.s. stått på egna ben i ett påföljande nummer av SVT. Alsmark hade antagligen ombetts fokusera på metodfrågan och precisera sin kritik till en eller två poänger. Enligt min mening har Alsmark i själva verket genomfört en lektörsbedömning, som iklätts debattens dräkt. Hade det inte varit lämpligare att antingen refusera artikeln rakt av eller lämna synpunkterna till Wästerfors, så att han fått chansen att bearbeta artikeln om han velat uppfylla SVT:s krav? Är det inte så det brukar gå till när vetenskapliga tidskrifter bedömer insänt material? När artiklar bedöms intressanta för tidskriften ges författaren möjlighet att tillgodose lektörernas och redaktionens krav om originalitet, diskursivitet, kvalitet etc. Artiklar som anses ha för stora brister refuseras och författaren kan då välja att försöka på annat håll. Vi måste ju ha klart för oss att vissa av de brister en redaktion eller lektör uppmärksammar, från perspektivet som etnolog exempelvis, inte alls ses som brister av en annan redaktion/lektör.

Om artikeln hade så många brister, varför tog då Socialvetenskaplig tidskrift in den? För att dess sakinnehåll var så intressant, eller för att Alsmark skulle få möjlighet att "debattera" den? Jag tror som sagt att tidskriftens behandling av artikeln ska ses som ett försök att få till mer debatt. Min poäng här är att detta sätt att debattera en forskningsmetod utifrån brister i en artikel inte höjer utan sänker den kvalitet Alsmark själv är så mån om. För att kunna debattera som Alsmark gör, är det ju bra och inte dåligt när publicerade artiklar har olika brister. Ju fler brister, desto mer debatt. Jag menar dessutom att den debattform SVT nu experimenterar med kommer att minska snarareän öka intresset för att föra en seriös debatt om metodologi i tidskriften. Debattavdelningen kan få ett rykte om att vara den plats dit artiklar som inte gillas eller duger för tidskriftens andra avdelningar omplaceras. Jag uppmanar därför redaktionen att se över sin policy på ett sätt som skapar tydlighet och förtroende bland läsare och potentiella artikelförfattare.

Håkan Jönson

Doktorand i Socialt arbete, Lund 